\title{
PENINGKATAN PEMAHAMAN PESERTA DIDIK DALAM EKSPLORASI KONSEP LINGKUNGAN HIDUP DENGAN MENGGUNAKAN MODEL PEMBELAJARAN SIKLUS BELAJAR
}

\author{
NURHANA \\ SMA Negeri 3 Takalar \\ Email : hana231275@gmail.com
}

\begin{abstract}
ABSTRAK
Penelitian ini merupakan penelitian tindakan kelas untuk meneliti tentang pemahaman siswa mengenai pembelajaran geografi. Data yang terkumpul dari penelitian ini terdiri atas data hasil tes sebgai indicator hasil belajar siswa pada tiap tindakan yang kemudian disebut data kuantitatif dan data hasil observasi untuk mengetahui aktivitas guru selama pembelajaran berlangsung dengan menggunakan model pembelajaran siklus belajar (Learning cyle) yang kemudian disebut data kualitatif. Pencapaian pemahaman konsep siswa pada fase eksplorasi dalam pembelajaran dengan menggunakan model pembelajaran siklus belajar (Learning cycle) untuk tindakan pertama sebesar 83,87\% dan tindakan kedua sebesar 90,63\%. Pencapaian pemahaman konsep siswa pada fase pengenalan konsep dalam pembelajaran dengan menggunakan model pembelajaran siklus belajar (Learning cycle) untuk tindakan pertama sebesar 83,87\% dan tindakan kedua sebesar 90,63\%. Pencapaian pemahaman konsep siswa dalam pembelajaran dengan menggunakan model pembelajaran siklus belajar (Learning cycle) untuk tindakan pertama sebesar 80,65\% dan tindakan kedua sebesar 90,63\%. Pencapaian pemahaman konsep siswa pada fase aplikasi konsep dalam pembelajaran dengan menggunakan model pembelajaran siklus belajar (Learning cycle) untuk tindakan pertama sebesar $77,42 \%$ dan tindakan kedua sebesar 87,
\end{abstract}

Keywords: Peningkatan Pemahaman, Eksplorasi Konsep, Siklus Belajar

\section{ABSTRACT}

This research is a classroom action research to examine students' understanding of geography learning. The data collected from this study consists of test result data as an indicator of student learning outcomes in each action which is then called quantitative data and observational data to determine teacher activities during learning using a learning cycle learning model which is then called qualitative data. . The achievement of students' conceptual understanding in the exploration phase of learning by using the learning cycle learning model for the first action is $83.87 \%$ and the second action is $90.63 \%$. The achievement of students' conceptual understanding in the concept introduction phase in learning by using the learning cycle learning model for the first action is $83.87 \%$ and the second action is $90.63 \%$. The achievement of students' understanding of concepts in learning by using the learning cycle learning model (Learning cycle) for the first action is $80.65 \%$ and the second action is $90.63 \%$. The achievement of students' conceptual understanding in the concept application phase in learning by using the learning cycle learning model for the first action is $77.42 \%$ and the second action is 87 ,

Keywords: Understanding Improvement, Concept Exploration, Learning Cycle

\section{PENDAHULUAN}

Hasil belajar siswa kelas XI IPS 2 SMAN 3 Takalar semester I Mata pelajaran Geografi masih rendah. Dari data hasil ulangan harian siswa dapat diketahui bahwa masih banyak siswa kelas XI IPS 2 yang memperoleh nilai ulangan harian di bawah Kriteria Ketuntasan Minimum (KKM) yang telah ditetapkan yaitu 65 pada skala 100. KKM sendiri merupakan indikator yang ditetapkan oleh sekolah untuk mengukur keberhasilan belajar siswa di SMA Negeri 3 Takalar. 
Tercatat sebanyak 14 orang dari 32 jumlah keseluruhan siswa kelas XI IPS 2 belum mencapai KKM. Artinya sebesar 43,75 \% dari jumlah siswa kelas XI IPS 2 belum dapat menguasai materi pembelajaran dengan baik dan hanya 56,25 \% saja yang telah dinyatakan berhasil menguasai materi tersebut. Persentase pencapaian KKM ini mengindikasikan bahwa proses pembelajaran Geografi pada Kelas XI IPS 2 harus ditingkatkan.

Menurut guru bidang studi lainnya banyaknya siswa yang belum mencapai KKM karena mereka kesulitan dalam memahami konsep. Terbukti soal-soal yang mayoritas berisi konsepkonsep yang diberikan tidak bisa mereka jawab dengan tepat. Rendahnya tingkat pemahaman siswa terhadap konsep tersebut karena sulitnya materi yang bersifat fisik, penggunaan media yang terbatas dan kurang tepat, pemilihan metode ataupun model pembelajaran yang kurang sesuai dengan tujuan dan materi pembelajaran, penggunaan metode, model, dan media pembelajaran kurang kondusif bagi terjadinya peran aktif siswa dalam kegiatan pembelajaran.

Materi yang bersifat fisik biasanya banyak mengandung istilah istilah baru yang belum dikenal siswa sehingga memungkinkan siswa sulit mengetahui arti istilah - istilah tersebut. Istilah - istilah ini menyulitkan siswa untuk memahami konsep yang sifatnya fisik karena dari segi arti saja siswa sudah mendapat kesulitan.

Penggunaan media juga memungkinkan terhambatnya proses pembelajaran di kelas. Media ini bisa berperan dalam pembelajaran sebagai alat visualisasi sehingga bisa memudahkan guru dalam menyampaikan materi pembelajaran. Dalam penggunaan media yang dilakukan oleh guru kadang - kadang kurang tepat karena ketersediannya terbatas sehingga guru menggunakan media seadanya. Akibatnya media tidak mempunyai peran apapun dalam proses pembelajaran bahkan bisa mempersulit siswa dalam memahami materi pelajaran. Hal ini yang akan terjadi kemudian adalah tujuan pembelajaran tidak dapat terpenuhi sehingga pembelajaran di kelas kurang berhasil. Maka penggunaan media harus tepat guna dan keterbatasan media bisa diatasi dengan kreatifitas guru dalam membuat media yang dapat membantu pembelajaran di kelas.

Selain penggunaan media yang terbatas dan kurang tepat, pemilihan metode ataupun model pembelajaran sering tidak sesuai dengan materi pembelajaran dan tujuan pembelajaran yang hendak dicapai. Pemilihan metode ataupun model pembelajaran hendaknya menyesuaikan dengan kompetensi pembelajaran yang diharapkan pada materi tersebut. Ketepatan dalam memilih metode atau model pembelajaran akan mempermudah pelaksanaan pembelajaran di kelas sehingga kompetensi dan tujuan pembelajaran dapat tercapai dengan baik

Hal lain yang bisa menghambat ketercapaian hasil belajar adalah penggunaan metode, model, dan media panbelajaran kurang kondusif bagi terjadinya peran aktif siswa dalam kegiatan pembelajaran. Seperti yang kita pada guru Artinya dominasi guru di dalam kelas selama pembelajaran sudah tidak sesuai dengan hakikat pembelajaran. Pembelajaran harus berlangsung secara dua arah sehingga tajadi komunikasi yang baik antara guru sebagai pendidik dengan siswa sebagai peserta didik. Siswa harus aktif selama pembelajaran tidak hanya menjadi pendengar setia dari seorang guru yang sedang menyampaikan materi pelajaran. Siswa akan aktif dalam pembelajaran apabila situasi dan kondisi mendukung terhadap aktivitas siswa. Penggunaan metode, model, dan media pembelajaran harus bisa membuat siswa nyaman ketahui bahwasannya pembelajaran di kelas pada saat ini tidak lagi berpusat sehingga suasana kondusif dalam mendukung kegiatan pembelajaran. Artinya baik dari mulai pemilihan sampai pada penggunaan metode, model, dan media harus benar-benar sesuai kondisi kelas dan siswa sehingga dapat menciptakan situasi pembelajaran yang kondusif bagi terciptanya peran aktif siswa dalam pembelajaran.

Berdasarkan masalah yang telah dipaparkan di atas maka diperlukan perbaikan dalam proses pembelajaran. Salah satunya dengan memłlih model pembelajaran yang bisa mengatasi permasalahan siswa yang kesulitan dalam memahami konsep. Model pembelajaran yang dipilih adalah model pembelajaran yang benar-benar menekankan pada aspek pemahaman konsep memahami konsep tersebut diharapkan siswa sendirilah yang dengan aktif membentuknya 
bukan hasil dari meniru atau menghapal apa yang dijelaskan oleh guru. Siswa memperoleh pengetahuan berupa pemahaman konsep melalui pengenalan konsep pada benda atau fenomena yang konkrit dan pengalaman mereka sendiri yang dapat berupa kegiatan mengeksplorasi, mengenali, dan kemudian mengaplikasikan konsep tersebut dalam kehidupan sehari-hari.

Model pembelajaran yang memiliki kriteria seperti apa yang dikemukakan di atas adalah model Pembelajaran Siklus Belajar (Learning cycle). Oleh karena itu pada penelitian ini penulis akan melakukan pembelajaran dengan menggunakan Model Pembelajaran Siklus Belajar (Learning cycle) yang dilandasi oleh pandangan konstruktivisme yang sehingga siswa dapat memahami konsep dengan baik. Dalam upaya menyatakan bahwa dalam proses pembelajaran guru tidak hanya memindahkan pengetahuan kepada peserta didik dalam bentuk yang sempurna atau utuh, tetapi peserta didik harus membangun suatu pengetahuan itu berdasarkan pengalamannya masing - masing. Model Pembelajaran Siklus Belajar (Learning cycle) terdiri dari fase eksplorasi, pengenalan konsep, dan aplikasi konsep. Melalui kegiatan pembelajaran dengan menggunakan Model Pembelajaran Siklus Belajar (Learning cycle) diharapkan pemahaman konsep siswa dalam eksplorasi, pengenalan konsep, dan aplikasi konsep dapat meningkat.

\section{METODE PENELITIAN}

Penelitian ini tergolong penelitian Tindakan Kelas yang meneliti penggunaan Model Pembelajaran siklus belajar yang terdiri dari tiga fase yaitu åse eksplorasi, fase pengenalan konsep, dan fase aplikasi konsep. Ketiga fase tersebut secara sistematis akan dilakukan dalam proses pembelajaran guna menjawab pertanyaan-pertanyaan penelitian Fase Eksplorasi, memberikan kesempatan secara langsung kepada siswa untuk mengungkapkan pengetahuan awalnya dalam observasi, mengembangkan pengetahuan baru, memahami fenomena alam, dan mengkömunikasikan pada orang lain. Fase Pengenalan konsep, guru memulai mengenalkan tentang suatu konsep atau istilah baru yang mengacu pada hasil penemuan pada eksplorasi dengan menggunakan berbagai metode yang tepat serta media yang sesuai, dan Fase Aplikasi konsep, guru memberikan berbagai persoalan dengan konteks yang berbeda untuk diselesaikan oleh siswa dengan konsep yang telah mereka dapatkan pada fase kedua.

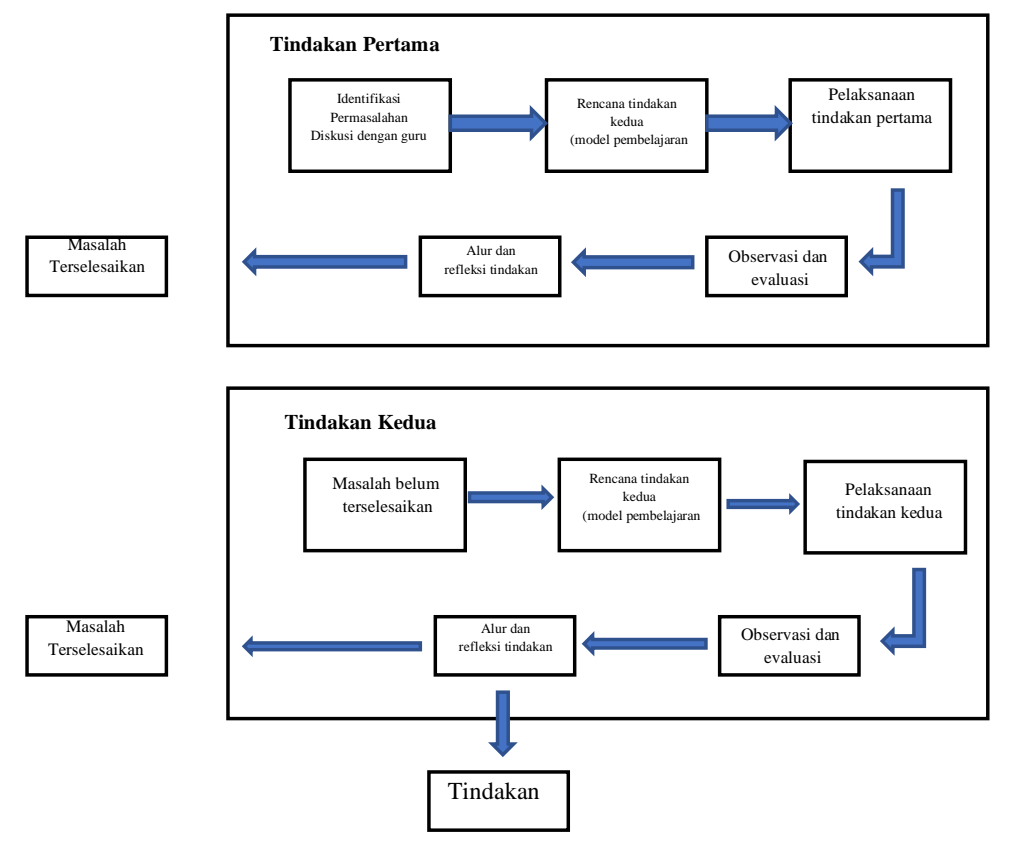

Berdasarkan alur prosedur penelitian di atas, pelaksanaan penelitian tindakan kelas diawali dengan identifikasi permasalahan oleh guru (dałam hal ini peneliti) kemudian mendiskusikannya dengan guru bidang studi yang bersangkutan kenka dirasa ada sesuatu yang mengganggu dan menghalangi pencapaian tujuan pembelajaran di dałam kelas. 
Dari identifikasi permasalahan yang ada dapat dilakukan diagłosis kemungkinan penyebab permasalahan yang terjadi sehingga akan diperoleh gambaran untuk melakukan alternatif tindakan dałam menyelesałkan permasalahan tersebut. Alternatif yang dinilai terbaik, kemudian kita buat rencana tindakannya. Rangkaian proses pembelajaran sewaktu melakukan tindakan merupakan hal yang sangat penting dałam PTK, maka dalam pelaksanaan tindakan ini senantiasa dilakukan observasi oleh guru mitra. Hasil tindakan pada akhirnya akan dinilai dan direfleksi dengan mengacu pada kriteria kriteria sebelumnya. Setelah dianalisis dan direfleksi, apabila hasilnya telah menyelesaikan masalah maka penelitian dicukupkan sampąi tindakan pertama, namun apabila belum memenuhi kategori menyelesaikan masalah, maka dibuat perencanaan untuk tindakan selanjutnya sampai permasalahan dapat terselesaikan.

\section{HASIL DAN PEMBAHASAN}

\section{Hasil}

Penelitian ini dilakukan untuk menyelesaikan permasalah-permasalahan yang muncul ketika proses pembelajaran dilakukan di kelas XI IPS 2 SMA Negeri 3 Takalar. Studi awal yang dilakukan adalah berdiskusi dengan guru mata pelajaran Geografi mengenai proses pembelajaran serta bagaimana hasil belajar siswa pada bidang studi Geografi. Dari diskusi tersebut dapat diketahui ternyata banyak siswa yang mengalami kesulitan dalam memahami konsep-konsep. Hal ini dapat dilihat dari hasil belajar siswa setelah mengikuti pembelajaran yang disajikan pada tabel di bawah ini.

Tabel 1 Hasil Belajar Siswa Sebelum Tindakan

\begin{tabular}{|c|c|c|c|c|}
\hline No. & $\begin{array}{c}\text { Komponen Hasil } \\
\text { Belajar }\end{array}$ & $\begin{array}{c}\text { Tes } \\
(0-100)\end{array}$ & $\begin{array}{c}\text { Tugas } \\
(0-100)\end{array}$ & $\begin{array}{c}\text { Hasil Belajar } \\
\text { Siswa }\end{array}$ \\
\hline 1. & Rata-rata Nilai & 66,16 & 64,34 & 65,25 \\
\hline 2. & Nilai terting $\varnothing$ & 76 & 70 & 74 \\
\hline 3. & Niiai terendah & 50 & 55 & 52,5 \\
\hline 4. & Jumlah siswa $\geq 65$ & $20(62,5 \%)$ & $22(68,75 \%)$ & $22(68,75 \%)$ \\
\hline 5. & Jumlah siswa $\leq 65$ & $12(37,5 \%)$ & $10(31,25 \%)$ & $10(31,25 \%)$ \\
\hline
\end{tabular}

Dari data hasil belajar siswa sebelum tindakan di atas, tercatat hanya 22 siswa atau $68,75 \%$ dari 32 jumlah siswa keseluruhan yang mampu mencapai KKM selebihnya 10 siswa atau $31,25 \%$ belum mencapai KKM.

Terhadap siswa yang belum mencapai KKM, maka guru melakukan remedial agar seluruh siswa mencapai KKM. Kondisi ini mengindikasikan bahwa pembelajaran Geografi masih belum mencapai ketuntasan belajar yang telah ditetapkan sebelumnya yaitu sebesar $80 \%$. Ketuntasan belajar ini menjadi acuan dalam menentukan keberhasilan siswa pada materi tertentu sehingga siswa yang telah mencapai KKM bisa melanjutkan pada materi selanjutnya.

Tindakan pembelajaran yang dilakukan oleh guru sebelumnya yaitu siswa langsung untuk mengerjakan latihan soal yang ada pada buku Lembar Kerja Siswa (LKS). Ketika pembelajaran dimulai guru memeriksa siswa apakah mereka membawa LKS atau tidak. Kemudian guru menyuruh siswa untuk membaca ringkasan materi yang akan dibahas yang dilanjutkan dengan mengerjakan seluruh soal-soal yang ada dalam LKS tersebut. Apabila ada yang kurang dimengerti oleh siswa maka bisa secara langsung ditanyakan pada guru yang bersangkutan. Bagian terakhir pembelajarzn, guru meminta agar buku LKS dikumpulkan untuk dipenksa. 
Hasil pekerjaan siswa ini menjadi patokan seberapa jauh siswa memahamł pokok bahasan tersebut.

Mereka cukup terampil dalam mengisi LKS namun ketika ditanya apakah mereka mengełti dengan apa yang mereka tulis ternyata tidak demikian. Artinya mereka hanya memindahkan tulisan yang ada dalam ringkasan materi kedalam bentuk jawaban soal-soal yang ada pada LKS saja tetapi pemahaman atas materi pelajaran tersebut belum diperoleh.

Pemahaman konsep siswa baik dalam eksplorasi, pengenalan konsep, maupun apllkasi konsep sama sekali belum tergali.

Pembelajaran yang dilakukan bertujuan agar semua materi cepat tersampałkan pada siswa meskipun tujuan kompetensi dasar belum sepenuhnya tercapai. Banyaknya materi yang harus disampaikan dengan alokasi waktu sedikit menjadi alasan pembelajaran semacam itu dilakukan oleh guru. Pembelajaran seperti ini untuk sementara dapat dikatakan sebagai cara paling efektif dalałîl pembelajaran di kelas karena dengan cara ini semua materi dapat tersampaikan dengan cepat pada siswa. Akan tetapi pembelajaran bukan hanya menyampaikan semua materi pada siswa melainkan ketercapaian kompetensi merupakan hal urgen yang harus diperhatikan. Pemahaman siswa terhadap materi yang disampaikan merupakan hal terpenting disamping pencapaian guru dalam menyelesaikan tugasnya menyampaikan seluruh materi pembelajaran.

Berdasarkan data hasil belajar siswa sebelum tindakan di atas selanjutnya dilakukan refleksi. Hasil refleksi menyimpulkan perlu diadakannya suatu tindakan guna memperbaiki proses pembelajaran sehingga siswa mendapatkan pengetahuan utuh dari pembelajaran bukan hanya keterampilan mengisi soal-soal semata.

Tindakan yang dapat meningkatkan pemahaman konsep siswa baik pada eksplorasi, pengenalan konsep, maupun pada apllkasi konsep. Dengan demikian maka diadakan penelitian tindakan kelas dengan menggunakan model pembelajaran siklus belajar (learning cycle) guna memecahkan masalah.

\section{B. Pelaksanaan Penelitian}

Penelitian tindakan kelas ini dilakukan sebanyak satu siklus dengan dua tindakan yang menunjukan adanya peningkatan kemampuan pemahaman konsep siswa dalam eksplorasi, pengenalan konsep, dan apllkasi konsep pada tiap tindakan dengan menggunakan model pembelajaran siklus belajar (learning cycle).

\section{Tindakan Pertama}

a. Tahap persiapan

Adapun tahapan persiapan untuk tindakan pertama sebagai berikut:

1. Menyusun Rencana Pelaksanaan Pembelajaran (RPP) yang menggunakan model pembelajaran siklus belajar (learning cycle)

2. Menetapkan waktu pelaksanaan tindakan

3. Menyiapkan soal tes

4. Menyiapkan format observasi aktivitas guru pada pembelajaran

5. Menyiapkan rencana refleksi

b. Pelaksanaan tindakan

Tindakan yang dilakukan adalah berupa pelaksanaan pembelajaran dengan menggunakan model pembelajaran siklus belajar (learning cycle). Pembelajaran dilaksanakan pada hari sabtu 23 April 2015 kelas XI IPS 2 SMA Negeri 3 Takalar dengan alokasi waktu dua jam pelajaran (90 menit). pembelajaran dengan menggunakan model pembelajaran Slklus belajar (learning cycle) terbagi kedalam tiga tahapan yaitu pendahuluan, kegiatan inti, dan penutup. Untuk kegiatan inti terdiidari tiga fase yaitu fase eksplorasi, fase pengenalan konsep, dan fase aplikasi konsep. Untuk mengetahui sejauh mana tingkat keberhasilan pembelajaran dengan menggunakan model pembelajaran siklus belajar (learning cycle) pada akhir tindakan dilaksanakan tes. Tes terdiri atas tes uraian untuk mengetahui pemahaman konsep Siswa pada 
fase eksplorasi dan pengenalan konsep sedangkan tes uji petik kerja produk untuk mengetahui pemahaman konsep Siswa pada fase aplikasi konsep.

1. Hasil belajar

Hasil belajar siswa terdiri atas hasil tes uraian dan tes uji petik hasil produk yang tersaji pada tabel berikut:

Tabel 2. Hasil Belajar Tindakan Pertama

\begin{tabular}{|c|c|c|c|c|}
\hline No. & $\begin{array}{c}\text { Komponen Hasil } \\
\text { Beiajar }\end{array}$ & Uraian & $\begin{array}{c}\text { TB Uji Petik } \\
\text { Kerja Produk }\end{array}$ & $\begin{array}{c}\text { Hasil } \\
\text { Belajar Siswa }\end{array}$ \\
\hline 1. & Rata-rata Nilai & 73,61 & 67,10 & 70,36 \\
\hline 2. & Nilai Teninggi & 89 & 80 & 79 \\
\hline 3. & Nilai Terendah & 45 & 50 & 47,5 \\
\hline 4. & Jumlah Siswa $\geq 65$ & $26(83,87 \%)$ & $24(77,42 \%)$ & $25(80,65 \%)$ \\
\hline 5. & Jumlah Siswa $\leq 65$ & $5(16,13 \%)$ & $7(22,58 \%)$ & $6(19,35$ \\
\hline
\end{tabular}

Sumber: Hasil Penelitian

Hasil belajar Siswa pada tindakan pertama menunjukan masm ada 6 orang Siswa atau $19,35 \%$ yang mendapatkan nilai di bawah 65 akan tetapi secara keseluruhan 25 orang Siswa atau 80,65\% telah mencapai KKM. Hasil belajar ini diperoleh dari penggabungan nilai tes uraian dengan nilai tes uji petik kerja produk. Terhadap Siswa yang belum mencapai KKM, maka guru melakukan remedial agar seluruh Siswa mencapai KKM. Rata-rata hasil belajar Siswa tindakan pertama 70,36 dengan nilai tertinggi 79 dan terendah 47,5. Rata-rata nilai tes uraian Siswa tindakan pertama sebesar 73,6] dengan nilai tertinggi 89 dan terendah 45. Ratarata nilai tes uji petik kerja produk Siswa tindakan pertama sebesar 67,1 dengan nilai tertinggi 80 dan terendah 50.

Untuk melihat perbandingan hasil belajar tindakan pertama dengan hasil belajar sebeium tindakan dapat dilihat pada tabel berikut.

Tabel 3. Perbandingan Hasil Belajar Tindakan Pertama

\begin{tabular}{|c|c|c|c|}
\hline No. & Komponen Hasil Belajar & Sebelum Tindakan & Tindakan Pertama \\
\hline 1. & Rata-rata Nilai & 65,25 & 70,36 \\
\hline 2 & Nilai Tertinggi & 74 & 79 \\
\hline 3. & Nilai Terendah & 52,5 & 47,5 \\
\hline 4. & Jumlah Siswa $\geq 65$ & $22(68,75 \%)$ & $25(80,65 \%)$ \\
\hline 5. & Jumlah Siswa $\leq 65$ & $10(31,25 \%)$ & $6(19,35 \%)$ \\
\hline
\end{tabular}

Data tersebut menunjukan adanya peningkatan rata-rata nilai belajar siswa pada tindakan pertama sebesar 5,11 atau 7,26\% dari 65,25 menjadi 70,36 dengan nilai sebelum 
tindakan 74 dan nilai tertinggi pada tindakan pertama 79 mengalami peningkatan sedangkan nilai terendah sebelum tindakan 52,5 dan mlai terendah pada tindakan pertama adalah 47,5 mengalami penurunan. Jumlah siswa yang mencapai KKM pada tindakan pertama mengalami peningkatan sebesar $11,9 \%$ dari $68,75 \%$ sebelum tindakan menjadi $80,65 \%$ pada tindakan pertama

\section{2) Proses pembelajaran}

Pokok bahasan pada tindakan pertama yang dibahas sesuai dengan RPP tindakan pertama yaitu Lingkungan Hidup. Proses pembelajaran dengan menggunakan model pembelajaran Slklus belajar (learning cycle) dimulai dengan langkah-langkah yang sistematis pada tiap fase yang tertuang dalam RPP.

Pada fase eksplorasi, siswa diberi pengarahan untuk melihat berbagai objek geografi di sekitar kelas. Dari hasil pengamatan siswatersebut guru bertanya apakah objek-objek yang terlihat tersebut merupakan komponen-komponai lingkungan hidup.. Selanjutnya guru mengambil dua buah gambar mengenai kondisi lingkungan hidup yang memihki perbedaan (lingkungan hidup yang rusak dan terjaga). Dari kedua gambar tersbut, Guru bertanya perbedaan antara kedua gambar tersebut.

Siswa terlihat mulai berani mengeluarkan pendapat balk dalam bertanya maupun menjawab pertanyaan guru meskipun situasi pembelajaran yang dilakukan merupakan pembelajaran yang baru dan berbeda dengan pembelajaran sebelumnya. Secara garis besar pembelajaran pada fase ini telah berjalan dengan baik. Akan tetapi ada beberapa hal yang harus diperbaiki. Tidak semua siswa berani mengungkapkan pendapat, ada beberapa diantaranya tampak malu-malu bahkan tidak mau mengeluarkan pendapat. Alasannya karena takut salah sehingga siswa yang berani mengeluarkan pendapat ada beberapa orang saja dan cenderung anak yang sama.

Pada fase pengenalan konsep, guru memperkenalkan konsep Lingkungan Hidup. Guru bertanya mengenai pengertian lingkungan hidup menurut beberapa pakar dan salah satu siswa diberikan kesempatan untuk mengungkapkan faktorfaktor yang mempengaruhi sifat sumber daya alam. Guru bertanya tentang cam menjaga kelestarian lingkungan hidup. salah seorang siswa disunłh maju ke depan kelas untuk menyampaikan pemikirannya mengenai cara-cara menjaga kelestarian lingkungan hidup.

Siswa dengan seksama mengikuti langkah-langkah pembelajaran yang dilakukan oleh guru. Siswa memperoleh konsep baru yang berhubungan dengan materi pembelajaran yang akan disampaikan paa pertemuan kali ini. Prosesnya hampir sama dengan fase sebelumnya hanya sumber konsep yang diperoleh siswa pada kedua fase ini yang membedakannya. Guru memberikan aksi benłpa pertanyaan dan siswa memberikan reaksi dengan menjawab pertanyaan guru tersebut. Guru melemparkan pertanyaan pada siswa kemudian salah seorang siswa menjawab pertanyaan tersebut sedangkan siswa lain bisa memberikan komentar atau gagasan lain. Kesulitan yang dihadapi pada fase ini tidak jauh beda dengan yang terjadi pada fase sebelumnya. Tidak semua siswa berani mengełuarkan pendapat dan kecenderungan siswa yang sama yang berani menjawab atau mengeluarkan pendapat.

Pada fase aplikasi konsep, guru mengkondisikan siswa untuk menyiapkan alat tulis yang akan digunakan siswa membuat sketsa lingkungan hidup disekitar kita. Guru memberikan situasi yang berbeda dibandingkan dengan kedua fase sebelumnya. Pada fase aplikasi konsep siswa dihadapkan pada kondisi penerapan konsep yang telah diperolah pada sebuah produk yang bisa dihasilkan atau juga diterapkan pada kehidupan sehari-hari tergantung pada materi dan kompetensi yang hendak dicapai. Produk ini menjadi ukuran keberhasilan siswa pada fase yang bersangkutan.

Siswa terlihat asyik mengaplikasikan konsep-konsep tersebut. Ada beberapa siswa yang bertanya ketika dihadapkan pada sesuatu yang mereka anggap kumng dipahami. Siswa dituntut bukan hanya memahami konsep dalam bentuk abstrak tetapi dalam bentuk 
yang konkrit sehingga konsep tersebut dapat diaktualisasikan dalam bentuk yang bisa dilihat atau dinikmati.

Untuk aktivitas guru, langkah-langkah model pembelajaran siklus belajar (learning cycle) yang tertuang dalam RPP telah terpenuhi dengan baik. Namun maslah ada kekurangan yang harus diperbaiki yaitu dalam hal alokasi waktu sehingga ada bagian-bagian pembelajaran yang dilaksanakan belum optimal terutama pada fase aplikasi konsep. Selain itu guru kurang memberikan motivasi terhadap siswa selama pembelajaran sehingga semangat siswa berkurang ketlka memasuki jam pelajaran kedua. Hasil observasi terhadap guru selama pembelajaran tindakan pertama secara keseluruhan sebagai berikut:

a. Pada saat pembelajaran berlangsung, guru masih dominan memberikan pertanyaan sehingga siswa masih cenderung menunggu pertanyaan benkutnya dari guru tanpa ada inisiatif menanyakan sesuatu yang belum mereka pahami.

b. Guru kurang membenkan peluang untuk semua siswa bertanya maupun mengeluarkan pendapat.

c. Guru kurang memotivasi siswa selama proses pembelajaran berlangsung.

d. Tełlalu banyak pertanyaanyang diajukan oleh guru pada fase eksplorasi dan pada fase pengenalan konsep.

e. Guru kurang mengatur waktu dengan baik sehingga ada fase yang dilaksanakan kurang optimal terutama pada thse aplikasi konsep.

c. Refleksi

Hasil refleksi tindakan pertama akan dijadikan acuan berhasil atau tidaknya tindakan yang telah dilakukan. Dari refleksi yang dilakukan diperoleh kesimpulan sebagai berikut:

1. Siswa masih kurang aktif dalam mengajukan pertanyaan maupun mengeluarkan pendapat.

2. Guru masih mendominasi dalam memberikan pertanyaan.

3. Guru masih kurang dalam memberikan motivasi selama pembelajaran berlangsung.

4. Alokasi waktu yang tersedia belum sesuai dengan pelaksanaan.

5. Hasil belajar siswa pada fase aplikasi konsep masih belum memenuhi target sehingga perlu ditingkatkan.

Berdasarkan hasil refleksi di atas, maka penelitian tindakan pertama belum mengatasi permasalahan dan perlu dilaksanakan tindakan kedua. Pada tindakan kedua ini perlu adanya perbaikan terhadap kekurangan yang terjadi pada tindakan pertama guna mengatasi permasalahan, diantaranya:

1. Lebih banyak memberikan kesempatan pada siswa untuk mengemukakan pendapat ataupun bertanya sehingga guru tidak lagi mendominasi dalam memberi pertanyaan.

2. Untuk meningkatkan motivasi siswa dalam mengeluarkan pendapat atau bertanya maka dilakukan sistem reward. Bagi siswa yang mengeluarkan pendapat atau bertanya akan diberikan poin tambahan sehingga siswa terasa termotivasi.

3. Guru melakukan pemenejemenan waktu dengan baik selama pembelajaran berlangsung.

4. Meningkatkan hasil belajar siswa dalam pembelajaran terutama pada fase aplikasi konsep.

5.

\section{Tindakan Kedua}

a. Tahap persiapan

Adapun tahapan persiapan untuk tindakan pertama sebagai berikut:

1.Menyusun Rencana Pelaksanaan Pembelajaran (RPP) yang menggunakan model pembelajaran siklus belajar (learning cycle)

2.Menetapkan waktu pelaksanaan tindakan

3.Menyiapkan soal tes 
4.Menyiapkan format observasi aktivitas guru pada pembelajaran

5.Menyiapkan rencana refleksi

b. Pelaksanaan tindakan

Tindakan yang dilakukan adalah berupa pelaksanaan pembelajaran dengan menggunakan model pembelajaran siklus belajar (learning cycle). Pembelajaran dilaksanakan pada tanggal 14 April 2015 kelas XI IPS 2 SMA Negeri 3 Takalar dengan alokasi waktu dua jam pelajaran (90 menit). Kegiatan pembelajaran dengan menggunakan model pembelajaran siklus belajar (learning cycle) terbagi kedalam tiga tahapan yaitu pendahuluan, kegiatan inti, dan penutup. Untuk kegiatan inti terdiri dari tiga fase yaitu fase eksplorasi, fase pengenalan konsep, dan fase aplikasi konsep. Untuk mengetahui sejauh mana tingkat keberhasilan pembelajaran dengan menggunakan mode! pembelajaran siklus belajar (learning cycle) pada akhir tindakan dilaksanakan tes. Tes terdiri atas tesuraian untuk mengetahui pemahaman konsep siswa pada fase eksplorasi dan pengenalan konsep sedangkan tes uji petik kerja produk untuk mengetahui pemahaman konsep siswa pada fase aplikasi konsep.

1) Hasil belajar

Hasil belajar siswa terdiri atas hasil tes uraian dan tes uji petik hasil produk yang tersaji pada tabel berikut:

Tabel 4 Tabel Hasil Belajar Siswa

\begin{tabular}{|c|c|c|c|c|}
\hline No. & $\begin{array}{c}\text { Komponen Hasil } \\
\text { Belajar }\end{array}$ & $\begin{array}{c}\text { Tes } \\
\text { Uraian }\end{array}$ & $\begin{array}{c}\text { Uji Petik } \\
\text { Kerja Produk }\end{array}$ & $\begin{array}{c}\text { Hasil } \\
\text { Belajar Siswa }\end{array}$ \\
\hline 1. & Rata-rata Nilai & 74,03 & 70,16 & 72,09 \\
\hline 2. & Nilai Tertinggi & 85 & 80 & 82,5 \\
\hline 3. & Nilai Terendah & 55 & 60 & 60 \\
\hline 4. & Jumlah Siswa $\geq 65$ & $\begin{array}{c}29(90,63 \\
\%)\end{array}$ & $28(87,5 \%)$ & $29(90,63 \%)$ \\
\hline 5. & Jumlah Siswa $\leq 65$ & $3(9,27 \%)$ & $4(12,5 \%)$ & $3(9,27 \%)$ \\
\hline
\end{tabular}

Hasil belajar siswa pada tindakan kedua menunjukan masih ada 3 orang siswa atau 9,27\% yang mendapatkan nilai di bawah 65 akan tetapi secara keseluruhan 29 orang atau 90,63\% telah mencapai KKM. Hasil belajar ini diperoleh dari penggabungan nilai tes uraian dengan nilai tes uji petik kerja produk. Terhadap siswa yang belum mencapai KKM, maka guru melakukan remedial agar seluruh siswa mencapai KKM. Rata-rata nilai hasil belajar siswa tindakan kedua 72,09 dengan nilai tertinggi 82,5 dan terendah 60. Rata-rata nilai tes uraian siswa tindakan kedua sebesar 74,03 dengan nilai tertinggi 85 dan terendah Rata-rata nilai tes uji petik kerja produk siswa tindakan kedua sebesar 70,16 dengan nilai tertinggi 80 dan terendah 60 .

Untuk melihat perbandingan basil belajar tindakan kedua dengan hasil belajar tindakan sebelumnya dapat dilihat pada tabel berikut:

Tabel 5. Perbandingan Hasil Belaiar Tindakan Kedua

\begin{tabular}{|c|l|c|c|c|}
\hline No. & Komponen Hasil Belajar & $\begin{array}{c}\text { Sebelum } \\
\text { Tindakan }\end{array}$ & $\begin{array}{c}\text { Tindakan } \\
\text { Pertama }\end{array}$ & $\begin{array}{c}\text { Tindakan } \\
\text { Kedua }\end{array}$ \\
\hline
\end{tabular}


Vol 2. No 1. Januari 2022 P-ISSN : 2774-8022, e-ISSN : 2774-5791

\begin{tabular}{|c|c|c|c|c|}
\hline I. & Rata-rata Nilai & 65,25 & 70,36 & 72,09 \\
\hline 2 & Nilai Tertinggi & 74 & 79 & 825 \\
\hline 3. & Nilai Terendah & 52,5 & 47,5 & 60 \\
\hline 4. & Jumlah Siswa $\geq 65$ & $22(68,75 \%)$ & $25(80,65 \%)$ & $29(90,63 \%)$ \\
\hline 5. & Jumlah Siswa $\leq 65$ & $10(31,25 \%)$ & $7(19,35 \%)$ & $3(9,27 \%)$ \\
\hline
\end{tabular}

Sumber: Hasil Penelitan

Data tersebut menunjukan adanya peningkatan rata-rata nilai hasü belajar siswa pada tindakan kedua dari 70,36 menjadi 72,09 dengan nilai tertinggi tindakan pertama 79 dan nilai tertinggi pada tindakan kedua 82,5 mengalami peningkatan sedangkan nilai terendah tindakan pertama 47,5 dan nilai terendah pada tindakan kedua adalah 60 mengalami peningkatan. Jumlah siswa yang mencapai KKM pada tindakan kedua mengalami peningkatan sebesar 9,98\% dari $80,65 \%$ pada tindakan pertama menjadi $90,63 \%$ pada tindakan kedua.

2) Proses pembelajaran

Pokok bahasan pada tindakan kedua yang dibahas sesuai dengan RPP tindakan kedua yaitu Pelestarian Lingkungan Hidup. Hal ini disesualkan dengan pokok bahasan di sekolah. Proses pembelajaran dengan menggunakan model pembeiijzran Siklus belajar (leaming cycle) dimulai dengan langkah-langkah yang sistematis pada tiap fase yang tertuang dalam RPP.

Pada fase eksplorasi, dimulai dengan memperhatikan cuaca di dalam dan di luar kelas. Salah seorang siswa disuruh keluar untuk merasakan dan mengetahui bagaimana keadaan udara di luar kelas. Siswa yang ke luar kelas disuruh menyampaikan pada teman-temannya bagaimana keadaan udara di luar kelas. Apakah ada perbedaan keadaan udara antara di dalam kelas dan luar kelas. Selanjutnya guru menyampaikan kaitan tentang pengaiaman siswa tersebut dengan pokok bahasan yang akan disampaikan yaitu Pelestarian Lingkungan Hidup. Gum bertanya pada siswa tentang materi lingkungan hidup.

Siswa terlihat lebih berani mengeluarkan pendapat baik dalam bertanya maupun meujawab penanyaan gum bila dibandingkan dengan pernbelajaran sebe!umnya. Secara keselunthan pembelajaran pada fase ini telah mengalami peningkatan. Siswa-siswa berani mengungkapkan pendapat tanpa ada perasaan takut malu seperti pada pembelajaran tindakan pertama dan kecenderungan anak yang sama dalam menjawab pertanyaan dan bertanya seperti pada tindakan sebelumnya sudah mulai ada perbaikan pada tindakan kedua ini. Siswasiswa terlihat antusias dalam mengeluarkan pendapat dan hampir semua siswa berupaya untuhnendapatkan kesempatan mengeluarkan pendapat sehingga guru bisa mencoba mendengarkan pendapat dari siswa yang berbeda.

Pada fase pengenalan konsep, guru memperkenalkan aspek-aspek yang berkaitan dengan pelestarian lingkungan hidup. Guru bertanya pada siswa Gan beberapa orang siswa menjawab pertanyaan guru. Guru bertanya mengenai unsur lingkungan abiotik dan hayati dan beberapa siswa mengemukan pendapatnya dengan menjawab pertanyaan. Selanjutnya ada siswa yang bełtanya mengenai pemanfaatan unsur-unsur abiotik dan hayati bagi manusia. Guru melemparkan pertanyaan yang diajukan oleh siswa kepada siswa yanglain. Beberapa orang siswa menjawab pertanyaan yang diajukantemannya.

Siswa dengan seksama mengikuti langkah-langkah pembelajaran yang dilakukan oleh guru. Prosesnya hampir sama dengan fase sebelumnya hanya sumber konsep yang diperoleh siswa pada kedua fase ini yang membedakannya.

Dominasi guru dalam memberikan pertanyaan selama pembelajaran berkurang bila dibandingkan pada tindakan sebelumnya yang didominasi oleh pertanyaan guru. Pembelajaran tampak lebih aktif karena siswa terlibat langsung dalam pembelajaran sehingga komunikasi dua arah terpenuhi dengan baik pada tindakan kedua ini. Kesulitan yang dihadapi pada tindakan 
pertama bisa diatasi pada tindakan kedua ini karena semua siswa terlibat dalam pembelajaran dan makin banyak siswa yang mengeluarkan pendapat sehingga kecenderungan siswa yang sama yang berani menjawab atau mengeluarkan pendapat tidak nampak pada tindakan kedua.

Pada fase aplikasi konsep, guru memberikan situasi yang berbeda dihandingkan dengan kedua fase sebelumnya.

Pada fase aplikasi konsep siswa dihadapkan pada kondisi penerapan konsep yang telah diperolah pada sebuah produk yang bisa dlhasilkan atau penerapan pada kehidupan sehari-hari tergantung pada materi dan kompetensi yang hendak dicapai. Guru mengkondisikan siswa dan menyuruh siswa untuk mempersiapkan alat tulis. Siswa kemudian disuruh membuat gambar ilustrasi yang berkaitan dengan materi yang diajarkan pada tahap ini.

Siswa terlihat aktif mengaplikasikan konsep-konsep tersebut. Ada beberapa siswa yang bertanya ketika dihadapkan pada sesuatu yang mereka anggap kurang dipahami. Pembelajaran pada fase ini lebih optimal dilaksanakan karena waktu yang tersedia tidak banyak tersita sepelti pada tindakan sebelumnya.

Untuk aktivitas guru, langkah-langkah model pembelajaran siklus belajar (learning cycle) yang tertuang dalam RPP telah ${ }^{\mathrm{s}}$ terpenuhi dengan baik Kekurangan yang harus diperbaiki selama tindakan pertama yaitu dalam alokasi waktu telah diperbaiki sehingga semua langkah pembelajaran dapat dilaksanakan dengan optimal terutama pada fase aplikasi konsep. Selain itu guru telah membenkan motivasi terhadap siswa selama pembelajaran sehingga semangat siswa tetap terjaga selama pembelajaran. Kecenderungan siswa yang sama dalam mengeluarkan pendapat baik dalam benanya maupun menjawab pertanyaan sudah teratasi dengan menerapkan sistem reward yaitu pemberian poin tambahan bagi mereka yang berani mengeluarkan pendapat. Observasi terhadap guru selama pembelajaran tindakan kedua secara keseluruhan sebagai berikut:

a. Siswa sudah aktif berpendapat baik dałam bertanya maupun menjawab pertanyaan sehingga kecenderungan siswa yang sama dałam berpendapat bisa teratasi.

b. Guru memberikan peluang yang sama pada semua siswa untuk mengeluarkan pendapat.

c. Guru bertindak scbagai seomng moderator dan motivator selama pembelajaran berlangsung.

d. Alokasi waktu sesuai dengan yang direncanakan.

\section{c. Refleksi}

Refleksi tindakan kedua terhadap pemahaman konsep siswa dengan menggunakan model pembelajaran siklus belajar (learning cycle) yang mengacu pada kriteria indikator keberhasilan dałam penelitian ini, maka penelitian kelas ini dapat disimpulkan tclah berhasil karena $80 \%$ siswa telah mencapai mencapai KKM. Kemampuan siswa dałam penguasaan konsep baik pada fase eksplorasi, fase pengenalan konsep, dan aplikasi konsep mengalami peningkatan pada tiap tindakan dan telah mencapai target penelitian.

\section{Pembahasan}

Penelitian tindakan kelas (PTK) ini berakhir setelah tindakan kedua karena telah mencapai indikator keberhasilan penelitian yang telah ditetapkan.

PTK ini dilaksanakan sebanyak satu siklus dengan dua kali tindakan. Pemahaman konsep siswa pada tindakan pertama sebesar $80,65 \%$ dan telah memenuhi indikator keberhasilan sedăngkan pada tindakan kedua sebesar $90,63 \%$ juga telah memenuhi indikator keberhasilan dan mengalami peningkatan dari tindakan sebelumnya. Pemahaman konsep siswa dałam eksplorasi pada tindakan pertama sebesar $83,87 \%$ telah memenuhi indikator keberhasilan sedangkan pada tindakan kedua sebesar $90,63 \%$ juga telah memenuhi indikator keberhasilan dan mengalami peningkatan dari tindakan sebelumnya. Pemahaman konsep siswa dałam pengenalan konsep pada tindakan pertama sebesar 83,87\% telah memenuhi indikator keberhasilan. Sedangkan pada tindakan kedua sebesar 90,63\% juga telah memenuhi indlkator keberhasilan dan mengalami peningkatan dari tindakan sebelumnya. Pemahaman 
konsep siswa dałam tindakan pertama sebesar 77,42\% belum memenuhi indikator keberhasilan sedangkan pada tindakan kedua sebesar $87,5 \%$ telah memenuhi indikator keberhasilan dan mengalami peningkatan dari tindakan sebelumnya. Maka data tersebut menunjukan penggunaan Model Pembelajaran Siklus Belajar (Learning cycle) dapat meningkatkan pemahaman konsep pada siswa kelas IPS 2 SMA Negeri 3 Takalar. Hal ini tentunya sesuai dengan yang diungkapkan oleh Muslim (2005:15) yang menjelaskan bahwa "model siklus belajar yang berorientasi pada pandangan konstruktivisme ini sangat memperhatikan pengalaman dan pengetahuan awal siswa serta bertujuan untuk meningkatkan pemahaman konsep siswa". Selain itu, kondisi seperti ini mencerminkan bahwa proses pembelajaran yang dilakukan telah mencapai tingkat keberhasilan karena salah satu keberhasilan proses pembelajaran dapat dilihat dari hasil belajar yang dicapai oleh siswa. Hasil belajar siswa dapat dilihat dari beberapa aspek seperti yang disampaikan oleh Sudjana (1995:62) benkut ini:

1. Pembahan pengetahuan, sikap dan perilaku siswa setelah menyelesaikan pengalaman belajamya.

2. Kualitas dan kuantitas penguasaan tujuan instruksional oleh para siswa.

3. Jumlah siswa yang dapat mencapai tujuan instruksional minimal 75 dari jumlah insuuksional yang harus dicapai.

4. Hasil belajar tahan lama diingat dan dapat digunakan sebagai dasar dalam mempelajari bahan berikutnya.

Salah satu aspek di atas dapat ditunjukan oleh hasil belajar siswa yang mengalami perubahan dari tiap tindakan. Perubahan yang nampak adalah peningkatan hasil belajar siswa yang menjadi salah satu indikasi bahwa telah terjadi perubahan pengetahuan pada siswa setelah menyelesaikan pengalaman belajamya. Pengetahuan sendiri merupakan bagian dari salah satu kemampuan yang dimiliki siswa s\&lah memperoleh pembelajaran seperti yang diungkapkan oleh Gagne (dalam Hasibuan, 2000:5) ada lima macam kemampuan hasil belajar tersebut adalah:

1. Keterampilan intelektual

2. Strategi kognitif, mengatur 'cara belajar' dan berfikir seseorang didalam arti seluasseluasnya, termasuk kemampuan memecahkan masalah

3. Informasi verbal, pengetahuan dalam arti informasi dan fakta.

4. Keterampilan motonk yang diperoleh di sekolah, antara Iain keterampilan menulis, mengetik, menggunakan jangka dan sebagainya.

5. Sikap dan nilai, berhubungan dengan arah serta intensitas emosional yang dimillki seseorang, sebagaimana dapat disimpulkan dari kecenderungannya bertingkah laku terhadap orang, barang atau kejadian.

Berdasarkan hasil observasi yang dilakukan selama pembelajaran tindakan pertama, guru dan Siswa telah melakukan kegiatan pembelajaran dengan menggunakan model pembelajaran siklus belajar (learning cycle), namun masih ada kekurangan-kekurangan yang datang dari guru maupun darisiswa seperti siswa masih kurang aktif dalam mengajukan pertanyaan maupun mengeluarkan pendapat, guru masih mendominasi dalam memberikan pertanyaan, guru masih kurang dalam memberikan motivasi selama pembelajaran berlangsung, alokasi waktu yang tersedia belum sesuai pelaksanaan, dan hasil belajar Siswa pada fase aplikasi konsep maslh belurn memenuhi target sehingga perlu ditingkatkan.

Melihat kekurangan yang masih ada maka penelitian dilanjutkan pada tindakan kedua dengan agenda utama memperbaiki kekurangan-kekurangan yang terjadi pada tindakan sebelumnya. Kekurangan-kekurangan yang harus diperbaiki pada tindakan kedua adalah lebih banyak memberikan kesempatan pada Siswa untuk mengemukakan pendapat ataupun bertanya sehingga guru tidak lagi mendominasi dalam memberi pertanyaan. Pada prinsipnya seorang pengajar atau guru berperan sebagai mediator dan fasilitator yang membantu agar proses belajar Siswa berjalan dengan baik. Hal ini sesuai dengan prinsip-prinsip konstuktivisme. Suparno (2001:96) menyatakan bahwa: Prinsip-prinsip yang sering diambil dari konstruktivisme 
antara Iain: (1) Pengetahuan dibangun oleh Siswa secara aktif, (2) Penekanan dalam proses belajar terletak pada siswa, (3) Mengajar adalah membantu Siswa belajar, (4) Penekanan dalam proses belajar mengajar lebih pada proses bukan pada hasil akhir, (5) Kurikulum menekankan partisipasi siswa, (6) Guru adalah fasilitator.

Untuk meningkatkan motivasi siswa dalam mengeluarkan pendapat atau bertanya maka dilakukan sistem reward. Bagi siswa yang mengeluarkan pendapat atau bertanya akan dibenkan poin tambahan sehingga siswa terasa termotivasi. Djamarah dan Aswan Zain (1995:149) menyatakan ada beberapa bentuk motivasi yang dapat digunakan guna mempertahankan minat anak didik terhadap bahan pelajaran yang diberikan. Bentuk-bentuk motivasi tersebut sebagai berikut: memberi angka, hadiah (reward), pujian, gerakan tubuh, memberi tugas, memberi ulangan, mengetahui hasil, dan hukuman.

Guru melakukan pemenejemenan waktu dengan baik selama pembelajaran berlangsung. Hal ini dapat dilakukan manakala guru konsekuen terhadap waktu yang tersedia yang sudah diatur secara matang dalam RPP. Masalah waktu inilah yang harus benar-benar diperhatikan guna terciptannya kelancaran pembelajaran.

Meningkatkan hasil belajar siswa dalam pembelajaran terutama pada fase aplikasi konsep. Kurang optimalnya pelaksanaan pembelajaran dalam aphkasi konsep pada tindakan pertama terkait dengan alokasi waktu yang sedikit karena banyak tersita pada bagian pembelajaran sebelumnya yaitu dalam eksplorasi dan pengenalan konsep.

Hasil observasi tindakan kedua menunjukan telah ada perbmkan proses pembelajaran

telah dilaksanakan dengan cukup berhasil sehingga berbagai permasalahan yang didiaßlosis ketika Tindakan Pertama dapat teratasi dengan baik serta memperoleh hasil yang optimal pula. Siswa yang aktif belpartisifasi dalam proses pembelajaran bertambah hal ini terjadi karena diberlakukannya sistem hadiah (reward) berupa penambahan poin sehingga mereka bersemangat dalam menjawab pertanyaan guru maupun dalam memberikan pendapat berupa ide atau gagasan. Kelancaran yang diperoleh pada fase eksplorasi dan pengenalan konsep berdampak positifpada penyediaan waktu untuk pelaksanaan fase aplikasi konsep tidak tersita sehingga pada fase tersebut pembelajaran dapat dilakukam dengan optimal.

Berdasarkan pada hasil penelitian tindakan di atas dapat diketahui bahwa semua target penelitian tindakan ini telah tercapai sehingga kita dapat menyimpulkan bahwa masalah sudah dapat teratasi. Dengan demikian, indikator keberhasilan dalam penelitian telah temenuhi yang berarti hipotesis tindakan telah terpenuhi pula yaitu penggunaan model pembelajaran siklus belajar (learning cycle) dapat meningkatkan pemahaman konsep siswa dalam eksplorasi, pengenalan konsep, dan aplikasi konsep pada materi Lingkungan Hidup di kelas X1 IPS 2 SMA Negeri 3 Takalar.

\section{KESIMPULAN}

Berdasarkan hasil penelitian ini, maka dapat disimpulkan bahwa penggunaan Model Pembelajaran Siklus Belajar (Learning cycle) ini dapat meningkatkan pemahaman konsep siswa kelas XI IPS 2SMA Negeri 3 Takalarpada pokok bahasan Lingkungan Hidup. Kesimpulan penelitian tindakan ini dapat diuraikan sebagai berikut:

1. Pencapaian pemahaman konsep siswa pada fase eksplorasi dalam pembelajaran dengan menggunakan Model Pembelajaran Siklus Belajar (Learning cycle) untuk tindakan pertama sebesar $83,87 \%$ dan tindakan kedua sebesar 90,63\%. Rata-rata pemahaman konsep siswa pada fase eksplorasi dalam pembelajaran dengan menggunakan Model Pembelajaran Siklus Belajar (Learning cycle) untuk dua tindakan tersebut sebesar $87,25 \%$ dan peningkatannya sebesar $6,76 \%$. Hasil pencapaian pemahaman konsep siswa dalam ekplorasi ini mengalami peningkatan dari sebelum dilakukan tindakan dan mengalami peningkatan pada tiap tindakannya.

2. Pencapaian pemahaman konsep siswa pada fase pengenalan konsep dalam pembelajaran dengan menggunakan Model Pembelajaran Siklus Belajar (Leaming cycle) untuk tindakan pertama sebesar 83,67 \% dan tindakan kedua sebesar 90,63\%. Rata-rata 
pemahaman konSep siswapada fase pengenalan konsep dalam pembelajaran dengan menggunakan Model Pembelajaran Siklus Belajar (Learning cycle) untuk dua tindakan tersebut sebesar $87,25^{\circ} / 0$ dan peningkatannya sebesar $6,76 \%$. Hasil pencapaian pemahaman konsep siswa dalam pengenalan konsep ini mengalami peningkatan dari sebelum dilakukan tindakan dan mengalami peningkatan pada tiap tindakannya.

3. Pencapaian pemahaman konsep siswa dalam pembelajaran dengan menggunakan Model Pembelajaran Siklus Belajar (Leaming cycle) untuk tindakan pertama sebesar 80,65\% dan tindakan kedua sebesar 90,63\%. Rata-rata pemahaman konsep siswa dalam pembelajaran dengan menggunakan Model Pembelajaran Siklus Belajar (Learning cycle) untuk dua tindakan tersebut sebesar $85,64 \%$ dan peningkatannya sebesar $9,98 \%$. Hasil pencapaian pemahaman konsep siswa ini mengalami peningkatan pada tiap tindakannya

4. Pencapaian pemahaman konsep siswa pada fase aplikasi konsep dalam pembelajaran dengan menggunakan Model Pembelajaran Siklus Belajar (Learning cycle) untuk tindakan pertama sebesar 77,42\% dan tindakan kedua sebesar 87,50\%. Rata-rata pemahaman konsep siswa pada fase aplikasi konsep umum dalam pembelajaran dengan menggunakan Model Pembelajaran Learning cycle untuk dua tindakan tersebut sebesar 82,46\% dan peningkatannya sebesar 10,08\%. Hasil pencapaian pemahaman konsep siswa dalam aplikasi konsep ini mengalami peningkatan dari sebelum dilakukan tindakan dan mengalami peningkatan dari sebelum dilakukan tindakan dan mengalami peningkatan pada tiap tindakannya.

\section{DAFTAR PUSTAKA}

Arikunto, Suharsimi. Suhardjono. dan Supardi. (2006). Penelitian Tindakan Kelas. Jakarta : Bumi Aksara. .

Djamarah, Syaiful Bahri \& Zain, Aswan. (1995). Strategi Belajar Mengajar. Jakarta: Rineka Cipta

Hamalik, Oemar. (2001). Proses BelajarMengajar. Jakarta : Bumi Akasara.

Haslbuan,J.J. dan Moedjiono. (2000). Proses BelajarMengajar. Bandung: Rosdakarya.

Isnawar. (2005). Pembelajaran Pesawat Sederhana dengan Model Siklus Belajar Empiris Indukif untuk Meningkatkan Pemahaman Konsep dan Kemampuan Berpikir Rasional Siswa SMP. Tesis Program Pasca Sarjana UPI. Bandung: Tidak Diterbitkan.

Komara. (2002). Miskonsepsi Siswa SMU Kelas 2 Pada Sub Pokok Bahasan Listrik Dinamis. Skripsi Jurusan Pendidikan Fisika FPMIPA UPI. Bandung: Tidak diterbitkan.

Muslim. (2005). Penerapan Model Siklus Belajar Dalam Pembelajaran IPA UntukMengubah Konsepsi Siswa Tentang Bunyi (Penelitian Tindakan Kelas di KelasSD Negeri di Bandung). Tesis PPS UPI. Bandung: Tidak Diterbitkan.

Sagala, Syaiful. (2005). Konsep dan Makna Pembelajaran. Bandung: Alfabeta.

Sudjana, Nana. (1989). Cara Belajar Siswa Aktif dalam Proses Belajar Mengajar. Bandung: Sinar Bam Offset.

Suparno, Paul. (2001). Filsafat Konstruktivisme Dalam Pendidikan. Yogyakarta: Kanisius. Susilo. (2007). Panduan Penelitian tindakan kelas. Yogyakarta: Pustaka Book Publisher.

Tatang. (2005). Penerapan Model Pembelajaran Learning cycle untuk Meningkaikan Pemahaman Siswa Kelas 11 SMA Pada Pokok Bahasan Getaran dan Gelombang. Tesis pada PPS UPI Bandung: tidak diterbitkan. 